\title{
Developing Corporate Entrepreneurship by Adopting Learning Practices of Startups
}

\author{
Grażyna Urbanik-Papp*
}

The concept of Lean Startup has revolutionized the creation of innovation in startups, as a way of accelerating learning and finding a functioning and profitable business model. How can the experience of startups benefit established companies whose culture is fundamentally different due to the organizational inertia? The development of corporate entrepreneurship could be aided by accelerated learning by iterations that constitute the key startup-specific practice. Strategic corporate entrepreneurship offers limited possibilities of implementing learning practices of startups and building a lean enterprise, whereas better conditions in this respect are created by corporate venturing. Interconnectedness between learning and other startup practices makes a new organization effective; however, it hinders the adoption of startup learning practices by established organizations.

Keywords: corporate entrepreneurship, Lean Startup, lean enterprise, organizational inertia, corporate venturing.

Submitted: 05.09.16 | Accepted: 20.10.16

\section{Rozwijanie korporacyjnej przedsiębiorczości poprzez wykorzystanie praktyk uczenia się start-upów}

Koncepcja Lean Startup zrewolucjonizowata tworzenie innowacji w start-upach, stanowita sposób na przyspieszenie uczenia się i znalezienie dziatajacego i zyskownego modelu biznesowego. W jaki sposób z doświadczeń start-upów moga skorzystać już istniejace korporacje, których kultura jest zasadniczo odmienna ze względu na inercję organizacyjna? Przyspieszone uczenie się przez iteracje stanowiace kluczowa praktyke specyficzna dla start-upów może pomóc w rozwijaniu korporacyjnej przedsiębiorczości. Strategiczna przedsiębiorczość korporacyjna oferuje ograniczone możliwości wdrożenia praktyk uczenia się start-upów i budowania korporacji lean, lepsze warunki $w$ tym względzie stwarza inwestowanie przez korporacje $w$ przedsięwzięcia podwyższonego ryzyka. Wzajemne zwiazki między uczeniem się a innymi praktykami startupów zwiększają skuteczność nowej organizacji, jednak utrudniają adaptację startupowych praktyk uczenia się przez już istniejące organizacje.

Słowa kluczowe: korporacyjna przedsiębiorczość, lean start-up, przedsiębiorstwo lean, inercja organizacyjna, korporacyjne inwestycje w przedsięwzięcia podwyższonego ryzyka.

Nadesłany: 05.09.16 | Zaakceptowany do druku: 20.10.16

JEL: 032

\footnotetext{
Grażyna Urbanik-Papp, PhD - Tischner European University in Kraków.

Correspondence address: Tischner European University in Kraków, Westerplatte 11 St., 31-033 Cracow, e-mail: gurbanik@wse.krakow.pl.
} 


\section{Introduction}

The business environment has changed dramatically in recent years. It means that not only individual entrepreneurs face a stern challenge when building profitable business, but also established organizations are forced into maintaining and developing their business by implementing innovations and entrepreneurial mindsets. In the reality of economic challenges that corporations face, the concept of corporate entrepreneurship is gaining importance. Implementation of corporate entrepreneurship is not an easy task, taking into account the rapid pace of changes in the business environment which, owing to this and other factors, is highly unpredictable. Owens and Fernandez (2014, p. 20) described 5 principles of "innovation game" crucial for entrepreneurs: 1 . Market changes take place in an unpredictable way, 2. Small teams are responsible for creating immense value, 3 . New markets are winnertakes-all, 4. Speed is an important source of competitive advantage, 5. Every success is preceded by a number of failures. To a certain degree, these principles influence each industry, but are particularly evident in hightech organizations.

Startups operate in an extremely unpredictable environment in order to find and harness external opportunities to build the value for the customer. In pursuit of tools effective in dealing with uncertainty, Eric Ries (2011) drew from his own experiences as a startup co-founder to develop the concept of lean startup, which has become very popular and widely used in startup communities. The concept has revolutionized the creation of innovation in startups as a way of accelerating learning and finding a functioning and profitable business model. The notion of Lean Startup can be used outside the immediate newly-formed-companies context and applied in other environments to translate startup experiences into established organization practices.

What merits attention in the context of corporate entrepreneurship is the question about the possible ways in which the startup experience can benefit established organizations whose culture is fundamentally different. The main goal of the article is to provide an answer to such a query by verifying the following statements:

1. Corporate entrepreneurship is limited by organizational inertia of established companies, which in turn is connected with the dynamic of sustaining and disruptive innovation.

2. To deal with factors impeding corporate entrepreneurship, established enterprises could adopt accelerated learning practices of startups, as recommended by the Lean Startup model.

3. Strategic corporate entrepreneurship offers limited possibilities of implementing the practices of accelerated learning, and better conditions in this respect are created by corporate venturing.

The hypotheses will be examined against the backdrop of theoretical reflection provided by the literature on the subject. It is worth underlining, however, that the cited publications regarding the notion of Lean Startup are written mainly by practitioners who are able to combine both practical experience and theory building. Therefore, the analysis remains firmly grounded in the practical experiences of high-tech industry specialists. It needs to be emphasized that high-tech companies represent the fastest evolving industry and could be treated as an indicator of changes that to some extent will exert substantial influence over all industries in the future. Adopting startup learning practices in the context of established companies should cast a new light on the concept of corporate entrepreneurship and open new avenues of inquiry for researches as well as practitioners in business management.

\section{Corporate Entrepreneurship}

Globalization, turbulent business environments as well as the rapid pace of technology development are among factors that render running an enterprise in a new economic reality a hazardous task. The concept of corporate entrepreneurship, constituting one of the established directions in entrepreneurship research (Sharma and Christman, 1999; Glinka, 2008; Oleksyn, 2012), is therefore gaining significance. It is defined by Sharma and Chrisman (1999, p. 17), who aimed at a reconciliation of different approaches, as: "the process whereby an individual or a group of individuals, in association with an existing organization, create a new organization or instigate renewal or innovation within that organization".

Established enterprises implement corporate entrepreneurship for a variety of 
reasons, as Kuratko, Hornsby and Hayton (2015) succinctly argue. Among the most important factors are: increasing profitability (Vozikis et al., 1999; cited in Kuratko et al., 2015), implementation of innovations (Baden-Fuller, 1995; cited in Kuratko et al., 2015), adoption of a new strategy (Guth and Ginsberg; cited in Kuratko et al., 2015), acquisition of knowledge necessary to build future revenue streams (McGrath et al.; cited in Kuratko et al., 2015), developing competitive advantage on the basis of resource configuration (Borch et al., 1999; cited in Kuratko et al., 2015), as well as expansion of international activity undertaken by multinational corporations (Birkinshaw, 1997; cited in Kuratko at al., 2015). Two main forms of corporate entrepreneurship are distinguished, namely: 1.) strategic entrepreneurship, 2.) corporate venturing (CV) (Morris, Kuratko and Covin, 2011; Sharma et al., 1999). Strategic entrepreneurship is manifested in companies as innovations in one of five areas: firm's strategy, product offerings, markets served, internal organization (structure, process and capabilities) and business model (Kuratko and Audretsch, 2013). Corporate venturing is, in its turn, divided into two categories of activities, which are internal and external. The former is defined as "corporate venturing activities that result in the creation of organizational entities that reside within an existing organizational domain" (Sharma et al., 1999, p. 20) and could vary in structural autonomy within the company, its degree of relatedness to existing business, extent of innovations in the market place (from imitative to "frame-breaking") and the nature of sponsorship, which means the degree of formal authorization for the venture (from "top-down" initiatives sponsored by organization to "bottom-down", informal, based on employees' entrepreneurial efforts) (Sharma et al., 1999; Day, 1994). In contrast to internal corporate venturing, the external mode "refers to the corporate venturing activities that result in the creation of semi-autonomous organizational entities that reside outside the existing organizational domain" (Sharma et al., 1999, p. 19), which could take different forms, e.g.: join-ventures, spin-offs, venture capital initiatives (Sharma et al., 1999). Kuratko, Hornsby and Hayton differentiate six main directions within the existing research referring to corporate entrepreneurship, which are: defining the concept, managing the people involved in $\mathrm{CE}$, implementation, metrics and assessment, CV and strategic entrepreneurship (2015, p. 249).

The idea to look at startups in order to find an inspiration for the development of an innovative mindset within corporations was previously expressed by Gary Hamel (1999). However, the Lean Startup model (Humble, Molesky and O'Reilly, 2015; Maurya, 2012; Müller and Thoring, 2012; Ries, 2011; Owens and Fernandez, 2014) widely used in startup communities after the year 2011 has become a new tool for achieving effectiveness in looking for a profitable business model and has changed a lot in startup-running. Accordingly, the Lean Startup approach provides a new perspective for the exploration of the concept of corporate entrepreneurship, which has been evolving over the last 40 years and gaining significance in the new economic reality.

\section{Factors Impeding \\ Entrepreneurship of Established Corporations}

Organizational inertia is responsible for blocking corporate entrepreneurship especially within established companies. The inertia is defined by Rumelt, who represents a resource-based view of the firm, as "the strong persistence of existing form and function", and "lack of plasticity" (Rumelt, 1995). According to research conducted by Le Mens, Hannan and Pólos (2015), the age of the organization exerts a negative influence over its speed of organizational change. Organizational inertia affects innovation, which has been proven empirically (Huang, Lai, Lin and Chen, 2013). While some authors focus on general organizational inertia (Cheng and Ja-Shen, 2013; Lazerson and Lorenzoni, 1999), others analyze specific kinds of inertia, e.g. inertia concerning structure (Colombo and Delmastro, 2002; Krzakiewicz, 2014), knowledge and learning (Liao, Fei and Liu, 2008).

Organizational ecologists Hannan and Freeman (1989) look deeper into the mechanisms of structural inertia and refer to it as a "speed of adjustment relative to the temporal pattern of key environmental changes", which means that the slower the 
changes inside the organization in relation to the environment, the greater the inertia. They list three internal arrangements leading to inertia: 1 ) resource-dependence: investment in equipment, plants or personnel are not easily transferable to different tasks and functions, 2) constraints on the information flow that prevent organizational decision makers from gaining access to the full information regarding the company. This implies that some organizational behaviors may depend on company history on one hand, and on the other, company history may block responsiveness to environmental changes, 3) internal politics which prevents the organization from relocating resources among its subunits, as such a move would be connected with disruption of the company's political equilibrium (Hannan and Freeman, 1989).

An important mechanism connected with organizational inertia is explained by Clayton Christensen in his classical work Innovator's Dilemma (1997), where he differentiates between sustaining and disruptive innovation. Sustaining innovation is focused on incremental changes to existing products and allows the incumbents companies holding an indicated position in the industry - to gain high profits according to the rule "incumbents nearly always win". As a result, the products are more complicated and expensive, because companies aim at satisfying the most demanding clients. This process unwittingly opens the door to disruptive innovation, which changes the whole industry, because thanks to new technology clients at the bottom of the market are able to receive at an affordable price the product accessible historically only to the customers at the top. Examples of disruptors are: personal computer for the mainframe computer industry, mobile phone for the fixed-line industry, discount retailers for full-service department stores. Each of these products was much cheaper and better satisfied the customer's needs, so in a short time it captured the market, providing a trailblazing example of the principle "entrants nearly always win", which describes implementing disruptive innovation.

From the market perspective, it is usually a new entrant that introduces disruptive innovation and wins the market after a period of sustaining innovation. Then the winner introduces sustaining innovations to the product until the next disruptive innovation emerges. The dynamic of sustaining and disruptive innovation creates a dilemma for the company, which sums up as a double-bind: whether to invest in the sustaining development of the existing product, which generates a flow of profits, or to work on disruptive innovation "killing" the effect of all current efforts. Usually, organizations select the first option. Very rarely does the established enterprise decide to invest in disruptive innovation to crowd out the existing product. A much more common situation occurs when a new company/startup entering the industry changes the market, taking advantage of disruptive innovation. Accordingly, the dynamic of sustaining and disruptive innovation casts light on an important dilemma faced by established companies, and instrumental in their decision-making processes that lead to opting for maintaining the status quo rather than risking losing the outcomes of their current efforts in the name of unproven innovation.

The factors impeding corporate entrepreneurship are an outcome of both organizational inertia and the innovator's dilemma, and take concrete forms observable in organizations, such as lack of autonomy, inappropriate incentives, financial structure (Owens and Fernandez, 2014), "command and control" approach, budgeting and financial management, program management based on creating detailed, upfront plans (Humble, Molesky and O'Reilly, 2015). Solutions potentially helpful in overcoming these obstacles to corporate entrepreneurship could be found in startups.

\section{Lessons Stemming from Startup Experiences}

Startups symbolize growth thanks to their almost uncanny ability to bring to the market new products and/or services of high value to the customers. Startups have opened vast new markets as in the case of Dropbox, Pinterest or Snapchat, which, as Owens and Fernandez do not fail to observe, are "the fastest-growing companies coming out of startup crucibles of Silicon Valley and New York" (2014, p. X). In a few years, they accrued valuations exceeding $\$ 10$ billion. What is very prestigious is the list of the so-called "unicorns", including 
startups which reached the value of more than $\$ 1$ billion. This can be at least partly explained by the cost of starting a company that is constantly dropping, especially in the typical technology-oriented startups. Some fixed costs are replaced by variable ones; as Owens and Fernandez note, such companies as Amazon Web Services "offer[s] aspiring entrepreneurs access to data infrastructure, which is free until customers start showing up en masse" (2014, p. X). Successful startups are able to find the product which will deliver value to the customer and ensure profit before they run out of their funds. However, most of them are unable to reach this goal and they fail according to the rules of the "innovation game", which imply very high risk for the players and very high reward for the winners.

Startups operate in an extremely uncertain environment; nevertheless, it does not mean that they are doomed to chaotic management, as Eric Ries underlines (2011). Ries combined the principles of agile project management, important especially for the software industry with lean management rules focused on continuous improvement, and successfully adopted them to be used in startup conditions as a tool named Lean Startup. Although Steve Blank's Customer Development approach (2015), agile software project management and lean management principles developed as the Toyota Manufacturing System ${ }^{1}$ (Humble, Molesky and O'Reilly, 2015; Womack and Jones, 1994) inspired Ries (Maurya, 2013), his experience as a cofounder of numerous startups was still of key importance. The approach is called by Ries "entrepreneurship management" (2011, p. 3) and supports founders of prospective "unicorns" in finding a profitable business model in the shortest possible time, which is of utmost importance, because resources for launching new business are limited.

In contrast to startups, established organizations aim at maintaining stable conditions for performing their activities in order to deliver standardized outcomes that are expected by the clients. Nevertheless, in developing corporate entrepreneurship the lessons stemming from Lean Startup are very valuable. Accelerated learning is crucial for dealing with uncertain environment, as in the beginning a startup team has only an idea of the product and conjectures on how it could be accepted by the market and how the client will use it. These two are key questions in a startup and finding the right answer to them constitutes the business model. It is unclear whether a new company will be able to make money out of the product even if the consumers accept it. A verified business model should meet two conditions, which are: 1.) problem/ solution fit, which means that the client has the need that is satisfied by the product, 2.) product/market fit, which is obtained when the sale of the product generates profits (Maurya, 2012). According to the Lean Startup model, in order to operate in such unpredictable conditions, a new company needs to form a hypothesis and test it by running experiments. As Owens and Fernandez claim, "the core of Lean Startup is experimentation, the application of scientific method to business" (2014, p. 84), which provides a concise definition of the way accelerated learning operates, by gaining information regarding the product and the market. In practice, as Maurya reports (2012), the startup team designs a simplified business model canvas that encompasses key operating premises regarding the proposed business model, keeping in mind that the final version will be different. Eric Ries (2011) explains step-by-step the experimental process necessary to verify the business model and obtain its final version. At first, the startup forms a hypothesis concerning the problem of the client and the solution offered by the product. Then, the riskiest assumption of the business model linked with the hypothesis is identified to be tested. In order to do this, test methods are selected and success criteria are established. The next step consists of building the mock form of the proposition for the client called the minimum viable product (MVP), which is the basic version offering only the necessary functions. The idea is to invest as few resources as possible in terms of time and money to create an MVP. After that, the experiment is run. The collection and analysis of the data allows for the assessment whether the set success criteria are met and this constitutes a basis for the decision to persevere if the results of the experiment are positive or pivot if the results do not support the hypothesis. Pivot is a term coined by Eric Ries (2011) and means the necessity to start again from the new hypothesis stage stemming from a new or profoundly modified business model. The whole cycle 
could be divided into three stages: build, measure and learn (Ries, 2011), as shown in Figure 1. Learning is of iterative nature, because while going through one loop of the cycle, the startup team obtains the information necessary to design a profitable business model or to start another loop. It results in accelerated learning, because thanks to planned experiments and loops of iterative learning, a new-formed company is able to learn a lot in a shorter period of time in comparison to the speed of learning in an average organization.

Figure 1. Loop of iterative learning of the buildmeasure-learn cycle

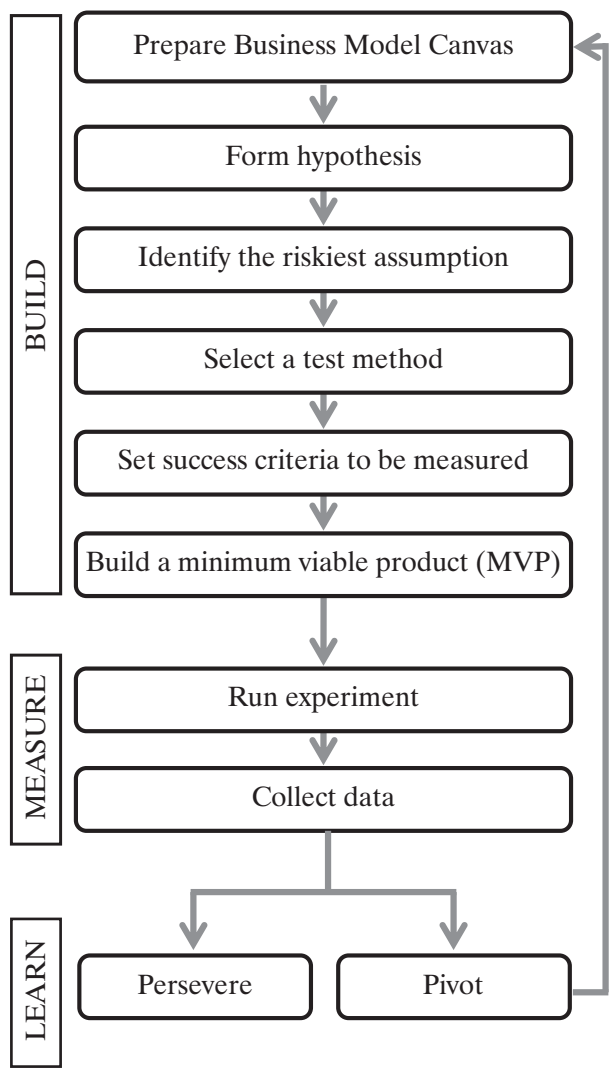

Source: my own flowchart based on Ries, 2011; Owens and Fernandez, 2015.

To conclude, learning by running experiments is a crucial part of the Lean Startup approach and turns out to be an iterative process with the clients' participation. It should be highlighted that it is important to involve a real customer in the experiments, because such an involvement makes for reliable results. The assumption behind the Lean Startup model is to reach the group of clients called innovators and early adopters that constitute respectively $2.5 \%$ and $13.5 \%$ of the whole client group according to Rogers's technology adoption lifecycle (2003). Put differently, in order to operate in the conditions of extreme uncertainty, a startup engages in the logical and ordered process of accelerated learning by iterations with real client participation.

As opposed to startups, an established company is used to operating in a more predictive environment, e.g. the budget for the current year is prepared on the basis of the previous years' financial plans. Iterative learning results are unpredictable, so this model does not suit the established enterprise's operative principles attached to procedures and standardization. Contrary to startups, established companies prefer to start new undertakings by elaborating a detailed business plan, which in fact is grounded in untested hypotheses and assumptions based on market research, but not proven by real customers. Aiming at high quality, companies devote a huge amount of resources to build the optimized final version of the product. However, it remains unknown whether the product will attract clients and generate profits until its final market entry.

As the article is focused on accelerated learning by iterations, other lessons stemming from startup experiences are beyond its scope, even though accelerated learning is only one of the organizational practices that could be adopted by established organizations. Nevertheless, it is of utmost importance to keep in mind that there are numerous factors contributing to creating an organizational system conducive to learning. Among startup-specific practices affecting iterative learning should be listed the following: high degree of the startup team autonomy, innovation accounting as well as incentives aimed at rewarding risktaking and entrepreneurial mindset. Moreover, the organizational culture embedded in the "mission command" management style instead of the "command and control" approach fundamentally influences the way the startup operates. In other words, an interconnected network of numerous factors is responsible for startup-specific practices, and this multifacetedness is exactly 
the reason why it is not easy for established organizations to adopt startup solutions.

Despite the fact that transferring the Lean Startup model into established organizations is a difficult task, iterative learning could aid companies in copying with uncertainty as well as in improving the efficiency of their entrepreneurial activities, provided that the company is able to face internal obstacles to entrepreneurship and build what can be called a "lean enterprise". It is worth highlighting that the issue of implementing startup practices in established organizations is tied with terminological ambiguities accrued to the very use of the term. Some authors (Humble et al., 2015) use the term "lean enterprise" to describe a company adopting general lean tools for product development, while others (Ovens et al., 2014) refer to implementing the Lean Startup model as developed by Ries (2011). Furthermore, a manufacturing company running its production according to the classical lean rules could be also defined as a "lean enterprise" (Womack and Jones, 1994). As a matter of fact, the Lean Startup concept derives from general lean principles. However, as we can see, the term "lean enterprise" is general and can relate to different organizational practices connected with implementing lean principles. In the case of this article, the term refers to adopting Lean Startup model practices in established organizations.

The connection between general lean practices and Lean startup can be examined via an analysis of three important elements of the Lean Startup approach that come from the Toyota Manufacturing System, namely: 1 . focusing on producing value as defined by the customer, 2 . reducing waste (also waste of time), 3. organizational learning incorporated into company procedures, which prevents the organization from inertia. Toyota developed efficient methods of lean principles implementation in manufacturing, but a direct transfer of these practices to startups has been impossible due to essential differences between these two kinds of organizations. What was more transferable were Toyota's lean product development system practices, but the transfer could not be total, as the approach supportive for large companies was inadequate for startups. Such guidelines as: "integrate suppliers into product development system", "organize to balance functional expertise and cross-functional integration", "develop towering competence in all engineers" (Morgan and Likert, 2006) were not applicable for the startup Therefore, Ries's contribution was to apply lean general principles to the startups specificity and needs. He also drew from Blank's Customer Development Methodology (Blank, 2005) and agile project management (Chrapko, 2013; Picher, 2010) focused on iterations helpful in learning how to satisfy clients expectations.

What merits attention is the fact that overlapping stages of product development have been observed by Takeuchi and Nonaka (1995) in innovative Japanese companies and are characteristic of concurring engineering. There are two strategies of coordination while implementing concurring engineering, set-based and iterative (Terwiesch, Loch and Meyer, 2002). Toyota adopted the set-based concurrent engineering approach to product development, which has been noted by Sobek, Ward and Liker (1999). This kind of theoretical awareness provides a springboard for the discussion of lean enterprise building.

\section{Lean Enterprise in Practice}

Organizational inertia and the innovator's dilemma result in a wide array of practices which impede entrepreneurship within established companies. On the one hand, corporate entrepreneurship is very important for companies, on the other, established organizations are run differently from startups, and overcoming internal obstacles to entrepreneurship is a stern challenge. The same concerns should be raised with reference to accelerated learning by iterations, which constitutes the key practice of the Lean Startup approach and provides an avenue for verifying a business model and obtaining problem/solution fit and product/market fit. This way of working on new products is opposite to the management of development projects in established organizations. Table 1 contains the summary of differences between the traditional approach to developing new products and the Lean Startup approach.

Nevertheless, an established company is able to adopt accelerated learning in order to enhance its capability of operating in an uncertain environment, which is necessary for entrepreneurial activity. In this way, the company develops corporate entrepreneur- 
Table 1. Comparison of approaches to new product development

\begin{tabular}{|c|c|c|}
\hline Comparison criteria & Traditional project management & Lean Startup model \\
\hline $\begin{array}{l}\text { Form of the business } \\
\text { plan }\end{array}$ & $\begin{array}{l}\text { detailed with projection of the budget, } \\
\text { planned sales and profit figures }\end{array}$ & $\begin{array}{l}\text { simplified business model canvas } \\
\text { encompassing key operating } \\
\text { assumptions }\end{array}$ \\
\hline $\begin{array}{l}\text { Goal of the business } \\
\text { plan }\end{array}$ & to be approved and implemented & to be verified by examination \\
\hline $\begin{array}{l}\text { Data available } \\
\text { for business plan } \\
\text { preparation }\end{array}$ & $\begin{array}{l}\text { market research, prior experiences } \\
\text { regarding this category of products } \\
\text { and this category of clients }\end{array}$ & $\begin{array}{l}\text { no market to be tested, } \\
\text { no prior experiences available }\end{array}$ \\
\hline Product building & final product is built & $\begin{array}{l}\text { minimum viable product (MVP) } \\
\text { is built after reaching problem/ } \\
\text { solution fit }\end{array}$ \\
\hline $\begin{array}{l}\text { Problem/solution fit of } \\
\text { the business plan }\end{array}$ & $\begin{array}{l}\text { assumed on the basis of prior } \\
\text { experience }\end{array}$ & $\begin{array}{l}\text { tested and verified by } \\
\text { interviewing and running } \\
\text { experiments on real clients }\end{array}$ \\
\hline Product/market fit & $\begin{array}{l}\text { assumed on the basis of prior } \\
\text { experience, simulations, market } \\
\text { research }\end{array}$ & $\begin{array}{l}\text { tested and verified on real } \\
\text { customers by involving them in } \\
\text { using MVP }\end{array}$ \\
\hline $\begin{array}{l}\text { Basis for investment } \\
\text { decision }\end{array}$ & business plan & $\begin{array}{l}\text { MVP verified on real } \\
\text { customers }\end{array}$ \\
\hline $\begin{array}{l}\text { Possibilities of business } \\
\text { model change during } \\
\text { the realization phase }\end{array}$ & $\begin{array}{l}\text { no possibilities, approved business } \\
\text { plan is implemented }\end{array}$ & $\begin{array}{l}\text { pivot is implemented if the } \\
\text { business model is not supported } \\
\text { by examination results }\end{array}$ \\
\hline $\begin{array}{l}\text { Involving clients in the } \\
\text { process }\end{array}$ & $\begin{array}{l}\text { clients are offered the final product and } \\
\text { can participate in the market research } \\
\text { before preparing the business plan }\end{array}$ & $\begin{array}{l}\text { clients are involved in the } \\
\text { whole process of preparing the } \\
\text { MVP and the final product }\end{array}$ \\
\hline $\begin{array}{l}\text { Resources necessary } \\
\text { to verify the business } \\
\text { model }\end{array}$ & the cost of the entire project & $\begin{array}{l}\text { resources necessary to build the } \\
\text { MVP and conduct experiments }\end{array}$ \\
\hline Learning & $\begin{array}{l}\text { final conclusion is drawn after the } \\
\text { product is released }\end{array}$ & $\begin{array}{l}\text { iterative learning is embedded } \\
\text { in the entire process }\end{array}$ \\
\hline Business environment & $\begin{array}{l}\text { adjusted to operate in a relatively } \\
\text { predictive environment }\end{array}$ & $\begin{array}{l}\text { adjusted to operate in extremely } \\
\text { unpredicted environment }\end{array}$ \\
\hline
\end{tabular}

Source: my comparison on the basis of Humble et al. (2015); Maurya (2013); Ries (2011).

ship, which can take two forms of strategic corporate entrepreneurship or corporate venturing. The easiest way of incorporating accelerated learning by iteration is by creating external corporate ventures, which results in building organizational entities outside the existing organizational domain. Even when new companies are autonomous or semi-autonomous, they are independent enough to create their own organizational culture and to adopt accelerated learning as well as other important practices recommended by the Lean Startup model, such as innovative accounting or incentives aimed at rewarding an entrepreneurial mindset. When discussing internal corporate venturing involving the creation of new organizational forms inside an established organizational domain, it is necessary to take into consideration that the new organization forms vary in structural autonomy, degree of relatedness to existing business, the 
extent of innovations in the market place (from imitative to "frame-breaking") and the nature of sponsorship. Accordingly, all of these factors influence the possibility of adopting iterative learning by a new entity. A high level of structural autonomy and low relatedness to existing business are conducive to accelerated learning implementation, because they favor diversified organizational practices. High extent of innovations in the market place requires accelerated learning to cope with uncertain environment and forces the organization to adopt this practice. On the other hand, innovation of imitative nature is usually connected with acting in more predictable conditions, so learning by iteration cannot be seen as crucial for success. Formal authorization of the venture could have divergent influence on adopting iterative learning, so no generalization is possible. What can be offered instead is a look at a specific example.

Owens and Fernandez (2014) claim that practices aimed at enhancing entrepreneurship inside organizations are ineffective and suggest a special organizational form called "innovation colony", which in their opinion creates the best conditions for adopting startup practices thanks to the independence of organizational practices from the entire corporation. Adopting accelerated learning by iterations within an established company as a practice referring to strategic corporate entrepreneurship appears generally as the most difficult. The difference between development project management in an established company and the Lean Startup model is profound, as presented in Table 1; therefore, adopting accelerated learning requires serious changes in the operation of the entire organization. Nevertheless, it is possible to find organizational fields where it is probable to adopt accelerated learning. Software projects serve as an excellent example where iterative learning constitutes the basis for agile project management which is very popular among software department specialists (Humble et al., 2015; Chrapko, 2013; Pichler, 2010). Strategic corporate entrepreneurship can concern five areas: firm's strategy, product offerings, served markets, internal organization (structure, process and capabilities), business model (Kuratko and Audretsch, 2013). It could be assumed that innovations connected with new product development and entering new markets could be the most conducive to adopting iterative learning, because in the case of these activities we cooperate with external clients, just as startups do. Nonetheless, this supposition needs to be confirmed by further research. At this moment, the question remains open as to how to implement iterative learning in the case of strategic renewal, changes in the organizational structure, company processes and capabilities or its business model. These activities require involving employees as internal clients, so the model used by a startup should be modified for the internal organizational environment.

\section{Conclusions}

The above analysis reveals that the assumptions stated in the introduction are supported. Organizational inertia and the innovator's dilemma are among factors explaining internal obstacles of established companies to entrepreneurship. The Lean Startup approach recommends a specific way of verifying a business model and obtaining problem/solution and product/ market fit by applying a series of planned experiments, i.e. accelerated iterative learning which is characteristic of startups, but which could also be used to aid established companies in development of corporate entrepreneurship. Nevertheless, implementation of startup learning practices remains a significant challenge for established organizations owing to internal obstacles and the fact that startup successes and the creation of organizational environment conducive to learning are an outcome of a set of interconnected factors. The adoption of startup learning practices appears less complicated in the case of corporate venturing connected with a high degree of autonomy rather than in the case of strategic corporate entrepreneurship.

The key contribution of this study is to develop a framework for research concerning the adoption of startup practices by established organizations in order to enhance their entrepreneurial capabilities in the form of strategic corporate entrepreneurship and corporate venturing. The proposed framework opens new avenues for research, among which three main directions can be distinguished: 1.) other startup practices stemming from the Lean Startup 
Model and affecting iterative learning as well as interconnectedness of different factors, with the emphasis on autonomy; 2 .) adopting accelerated learning by iterations in different areas of strategic corporate entrepreneurship; 3.) different forms of new business entities created externally or internally as corporate venturing. Owing to the practical angle of the theoretical considerations both in the analysis conducted in the study and in the literature on the subject, the proposed framework remains firmly grounded in the recent business practice connected with using the Lean Startup model by startups.

\section{References}

Blank, S. (2005). The four steps to the epiphany. Pescadero: K\&S Ranc.

Cheng, C.J. and Ja-Shen, C. (2013). Breakthrough innovation: The roles of dynamic innovation capabilities and open innovation activities. Journal of Business \& Industrial Marketing, 28(5), 444-454. doi:10.1108/08858621311330281.

Chrapko, M. (2013). SCRUM. O zwinnym zarzadzaniu projektami. Helion.

Christensen, C.M. (2003). The innovator's dilemma: The revolutionary book that will change the way you do business. New York, NY: HarperBusiness Essentials.

Colombo, M.G. and Delmastro, M. (2002). The determinants of organizational change and structural inertia: Technological and organizational factors. Journal of Economics and Management Strategy, 11(4), 595-635. doi:10.1162/105864002320757271.

Day, D.L. (1994). Raising radicals: Different processes for championing innovative corporate ventures. Organization Science, 5(2), 148-172.

Glinka, B. (2008). Kulturowe uwarunkowania przedsiębiorczości $w$ Polsce. Warszawa: Polskie Wydawnictwo Ekonomiczne.

Hamel, G.(1999). Bringing Silicon Valley inside. Harvard Business Review, 77(5), 70-84.

Hannan, M. and Freeman, J. (1989). Organizational ecology. Harvard University Press.

Huang, H., Lai, M., Lin, L. and Chen, C. (2013). Overcoming organizational inertia to strengthen business model innovation: An open innovation perspective. Journal of Organizational Change Management, 26(6), 977-1002. doi:10.1108/JOCM-042012-0047.

Humble, J., Molesky, J. and O'Reilly, B. (2015). Lean enterprise: How high performance organization innovate at scale. O'Reilly Media, Inc.
Krzakiewicz, K. (2014). Zmiany w organizacji i strukturalna inercja. Research Papers of the Wroclaw University of Economics / Prace Naukowe Uniwersytetu Ekonomicznego we Wroclawiu, 340, 450-460. doi:10.15611/pn.2014.340.41.

Kuratko, D.F. and Audretsch, D.B. (2013). Clarifying the domains of corporate entrepreneurship. International Entrepreneurship and Management Journal, 9(3), 323-335.

Kuratko, D., Hornsby, J. and Hayton, J. (2015). Corporate entrepreneurship: The innovative challenge for a new global economic reality. Small Business Economics, 45(2), 245-253. doi:10.1007/ s11187-015-9630-8.

Lazerson, M. and Lorenzoni, G. (1999). Resisting organizational inertia: The evolution of industrial districts. Journal of Management and Governance, 3(4), 361-377. doi:10.1023/A:1009965510858.

Le Mens, G., Hannan, M.T. and Pólos, L. (2015) Age-related structural inertia: A distance-based approach. Organization Science, 26(3), 756-773. doi:10.1287/orsc.2015.0966.

Liao, S., Fei, W. and Liu, C. (2008). Relationships between knowledge inertia, organizational learning and organization innovation. Technovation, 28(4), 183-195. doi:10.1016/j.technovation.2007.11.005.

Maurya, A. (2012). Running lean: Iterate from plan A to a plan that works. O'Reilly Media, Inc.

Morgan, J.M. and Liker, J.K. (2006). The Toyota product development system (Vol. 13533). New York: Productivity Press.

Morris, M.H., Kuratko, D.F. and Covin, J.G. (2011). Corporate entrepreneurship and innovation. Cengage Learning.

Müller, R.M. and Thoring, K. (2012). Design thinking vs. lean startup: A comparison of two userdriven innovation strategies. Conference Proceedings of the 2012 International Design Management Research Conference, 151-161.

Narayanan, V., Yang, Y. and Zahra, S.A. (2009). Corporate venturing and value creation: A review and proposed framework. Research Policy, 38(1), 58-76. doi:10.1016/j.respol.2008.08.015.

Oleksyn, T. (2012). Przedsiębiorczość jako kategoria złożona. Jak ją rozwijać? Problemy Zarzadzania, 1(36), part 2, 8-25.

Owens, T. and Fernandez, O. (2014). The lean enterprise: How corporations can innovate like startups. John Wiley \& Sons.

Pichler R. (2010). Agile product management with Scrum. Creating products that customers love. In: Addison-Wesley Signature Series. Boston.

Ries, E. (2011). The lean startup: How today's entrepreneurs use continuous innovation to create radically successful businesses. Crown Books. 
Rogers, E.M. (2003). Diffusion of innovations. Free Press.

Rumelt, R.P. (1995). Inertia and transformation. In: C.A. Montgomery (ed.), Resource-based and evolutionary theories of the firm. Boston: Kluwer Academic Publishers.

Sobek II, D.K., Ward, A.C. and Liker, J.K. (1999) Toyota's principles of set-based concurrent engineering. MIT Sloan Management Review, 40(2), 67-83.

Sharma, P. and Chrisman, S.J.J. (1999). Toward a reconciliation of the definitional issues in the field of corporate entrepreneurship. Entrepreneurship Theory and Practice, 23(3), 11-28.
Takeuchi, H. and Nonaka, I. (1986). The new new product development game. Harvard Business Review, 64(1), 137-146.

Terwiesch, C., Loch, C.H. and Meyer, A.D. (2002). Exchanging preliminary information in concurrent engineering: Alternative coordination strategies. Organization Science, 13(4), 402-419.

Thornberry, N. (2001). Corporate entrepreneurship: Antidote or oxymoron?. European Management Journal, 19(5), 526-533.

Womack, J.P. and Jones, D.T. (1994). From lean production to lean enterprise. Harvard Business Review, 72(2), 93-103. 